\title{
Indicators for sustainable mobility in the cities
}

\author{
S. Amoroso, L. Caruso \& F. Castelluccio \\ Dipartimento dell'Energia, Sezione Trasporti, \\ Università degli Studi di Palermo, Palermo, Italy
}

\begin{abstract}
The creation of a sustainable transport system is the main objective of the European transport policy. This system should encourage facilities to connect all people and should be linked with economic, social and environmental aspects of society. Current trends and future challenges will meet a growing "accessibility" demand, highlighting concerns about the sustainability of transport. Therefore one of the priorities of transport policy is the improving of overall quality of transport, including aspects related to: personal safety, accidents and health hazards reduction, protection of passengers rights and of accessibility to remote areas.

This paper is dedicated to sustainable development, with particular attention to urban transport and to daily mobility of citizens. It is important to analyze all the aspects that make it possible to clarify a definition of "sustainable transport". Their analysis has to be related to the individuation of a set of indicators that simultaneously take into account the three dimensions of sustainability: environment, economy and social issues. This, set should help to take decisions on policy and planning of urban transport systems. A limited and easily available set of indicators is more convenient to be used, but it may overlook important impacts, thus distorting planning decisions. A broad set of indicators can propose more quality in terms of completeness, but it has characterized by incredible data collection costs and by serious difficulties of interpretation. This study is based on the results of a survey carried out to verify feasibility and usefulness of such indicators for sustainable urban mobility in a particular territory. Values assumed by economic, environmental and social indicators are referred to the city of Palermo. A survey on family shifts was carried out in this city. It aims to the creation of a set of indicators that would allow comparison between different urban transport strategies. Finally, we analyze the possibility to generalize the proposed
\end{abstract}


set of indicators and the role that they could play in sustainable transport policies development and implementation, even in different urban contexts.

Keywords: sustainability, indicators, urban transport.

\section{Introduction}

Many studies on sustainability of transport systems have been recently held, as sustainability has assumed high importance in the broader context of development. The objectives of these studies include the evaluation of public policy, the instruments to support decisions for the public information and the implementation of participatory processes. Most of them agree that, while transport systems provide essential services, they produce environmental, social and economic impacts too, mostly negative and not always taken into account. Dealing with the issue of sustainable mobility should be done through the development of strategies integrating urban planning, technological advances, behavioural changes and pricing policies into traditional transport ones. Strategies must be based on cross-cutting public choices: the question of transport can not be summed up in technical matters of adjustment between the supply of infrastructure and services with demand for mobility, but must be fully opened to public participation. Cities that have signed the Aalborg Charter (1994) have to base their decision-making and control activities on important monitoring systems (environmental, impact assessment, accounting, budget, audit and reporting), on different types of indicators, including those related to environmental quality, to flows and patterns of the towns and significantly to sustainability of urban systems. Many national and international studies have had different objectives: some stand the sensitivity for environmental aspects of transport policies, while others are addressing urban mobility in the context of a sustainable system. There are different types of indicators of sustainable development, which can be classified according to represented information (social, environmental or economic indicators), according to their qualitative or quantitative nature, according to assigned tasks (e.g., descriptive indicators, which measure the state of a system in relation to topic of sustainable development, and performance indicators, which are instruments of comparison between the results of descriptive indicators and benchmarks or policy goals). Indicator systems are the product of a compromise between the permanent scientific needs and requests of decision-making process that requires readily usable information in order to simplify complex phenomena data, providing accessible information to a broad audience. Figure 1 shows an information pyramidal graph, consisting of two triangles that connect the nature of the information with the public to whom it is addressed (Levarlet, 1999). The base represents the total amount of available information, which is more aggregated as it is made more accessible to people. The base of the first triangle contains raw data and is directed to researchers and experts, while the top (indicator systems or indexes) aims to the general public. On the one hand an analytical path aims to capture and explain complex phenomena, on the other a communication path aims to send short message to the community. 

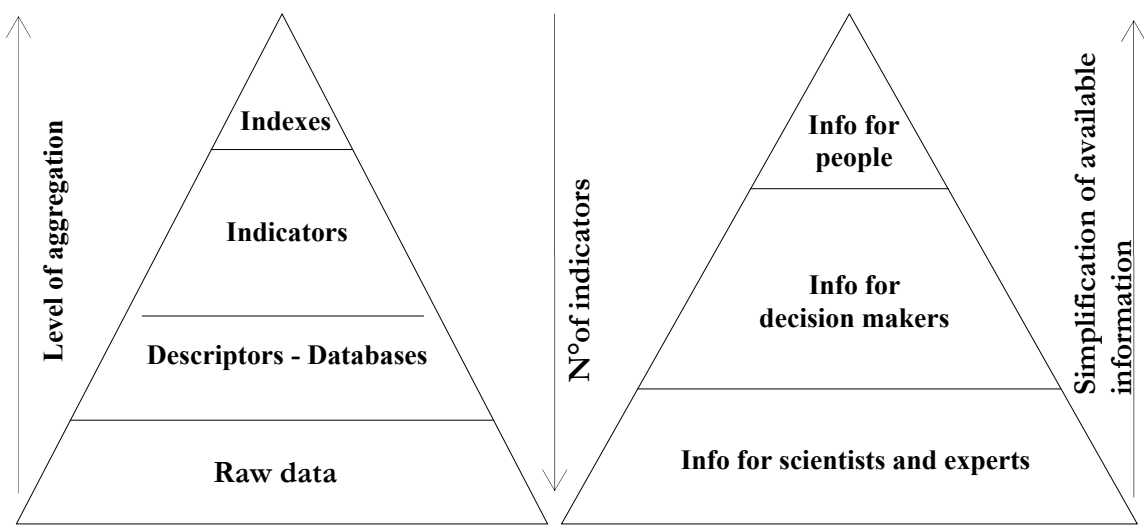

Total information amount

Source: Levarlet, 1999.

Figure 1: $\quad$ Links between information, targets and indicators system.

\section{Indicators of sustainable development and mobility}

Most of the studies are based upon the definition of sustainable development, which founds itself on the concept of sustainable transport and mobility drawn by the Brundtland Commission: "the transportation system has to meet the needs of individuals without compromising future generations' opportunities to satisfy their own requirements". But a more reliable definition of sustainable transportation system was adopted by the European Council of Transport Ministers in April 2001: "a sustainable transport system enables people, companies and communities to satisfy their own needs in terms of accessibility and development, safely and compatibly with human health and ecosystems, and it promotes equality within each generation and between generations; it is economically feasible, it operates with equality and efficiency, it offers a choice of transport mode and supports a competitive economy as well as balanced regional development; it limits emissions and waste than the planet's capacity to absorb them, uses renewable resources up to their rate of recovery or and nonrenewable resources above the rate of development of renewable substitutes, having a minimal impact on the use of natural resources and the production of nuisance". The Declaration of Principles of the Charter of Aalborg requires a commitment from European cities for a sustainable urban model and highlights the issues related to mobility, for which the same cities should be particularly active "... to improve accessibility and support social welfare and urban lifestyle, while reducing the mobility. A sustainable city has now the imperative requirement to reduce forced mobility and should not promote and support the 
unnecessary use of motor vehicles. The environmentally friendly means of transport (particularly walking, cycling and using public transport) should be preferred and planning efforts must converge in the realization of a combination of these means. The individual means of transport should have only an auxiliary function in the cities, to facilitate access to local services and maintain urban economic activities." It is necessary to understood how to evaluate the sustainability of a system of urban displacements, and even more so, how to modify the evolution of this system in the long term, to limit environmental harm, to contain costs, without neglecting social equity goals. A set of indicators could be a good instrument to evaluate these aspects, finding characteristics of coherence between the three dimensions of urban mobility, above mentioned. If these indicators are integrated into simulation models, they can provide important tools to support decisional processes of stakeholders, taking into account sustainable alternatives for development of urban transport. Studies on urban mobility can use disaggregated data that allow a full understanding of mobility and its consequences into the area. If environmental and economic indicators linked to transport are widely used, social indicators (i.e. equity, accessibility and quality of life) need specific analysis choices. Available data on population (i.e. income, location and age), urbanism (i.e. density, urban form and type of housing) and urban mobility allow the development of differentiated indicators that conduce to a disaggregated approach. In this way it's possible describe the emissions, their location and the responsible. Many studies are based on survey data of family movements. This methodology allows a socioeconomic analysis of mobility, which is important for some targets, but it gives only a partial view of mobility impact limited to the studied urban area.

\section{The problem of sustainability into urban mobility}

The city lives in an uneasy equilibrium condition between central areas and widespread habitat of suburbs. Each context has its own specific advantages and particular problems. Population density and territorial extension of these areas determine significant influences on the mobility of citizens: life in suburbs makes it necessary to use the car, while downtown offers much more diversified modal opportunities. The expansion of cities is a problematic aspect, because residents and workers suffer its effects for their shifts, which depend almost on private car. Urban environment is characterized by very different levels of environmental impacts, of costs and of social implications of transport, in terms of mobility. So it is important to compare the expressed mobility (and the actions it has taken) with its environmental, economic and social consequences. In this context, use of household surveys provides reproducible and comparable indicators in different cities. In addition, the detail of collected information on mobility can be re-aggregated by mode of transport, category of people or geographical area, according to analysis. Use of car is the primary factor in the consumption of public space for citizens' mobility in central areas, mainly due to the parking. The largest share of public space is devoted to the phase of movement of cars in suburban areas. The number of used indicators is high in 
many cases and their compatibility difficult. A key indicator can often be broken down into several sub-indicators (e.g. indicator of "emission of pollutants" is often fragmented into data on each type of pollutant and every mode of transport). So it is necessary to consider the main indicators among those identified and reported. It is important to reconsider the representation of urban planning-transportation system and to identify the elements that characterize the concept of sustainable mobility, in order to define a coherent indicators framework. First of all urban system can be described as the interaction of three sub-systems: localization, displacements, social relations. The subsystem of localization refers to different land uses and their spatial integration, the subsystem of movements consists on one hand on people and goods flows; on the other, by the transport system that allows the physical implementation of mobility. The subsystem of social relations is tied to society operating mode and to its activities. The subsystem of displacements determines the impact evaluation and it cannot be fully caught into its dynamics and its long-term evolutions, except through the interaction with the other two subsystems. The key concept that qualifies these relationships is accessibility. Its improvement is one of priorities of all transport policies in each spatial and social configuration. Its characterization has connotations of complexity because it mixes aspects of space, time and localization of activities, transport systems and social relations.

\section{Proposed mobility indicators}

In this study we propose a set of mobility indicators that are based on the offered transport services, costs and externalities due to the displacements within the urban environment. They also take into account the perspective of forecasts and the economic, environmental and social dimensions, as we can see into table 1 . If we consider produced services, accessibility is the primary factor to consider. Traditional "cost-time" model of transport economy can measure it. It also can be measured through the budget related to time and costs averagely used to access to principal activities: work and services consumption. This dimension has to be understood as the efficiency of overall system of displacements into urban areas.

Accessibility can be measured using the same "cost-time" model (budget linked to the time per day, daily cost per available modes of transport) even in "social" dimension, but by dividing the population into social categories, age, sex, place of residence and individual income. Considering the "environmental" area of performed displacement activities, only their negative impacts are taken into account. Displacement costs, mobility unit costs (average cost of a pass per $\mathrm{km}$ ), individual mobility costs (collective average cost per person per year), costs suffered by different actors (level of total annual cost for households, public administrations, etc.) should be considered in the "economic" dimension. $\mathrm{CO}_{2}$, $\mathrm{CO}$ and $\mathrm{NO}_{\mathrm{x}}$ emissions, hydrocarbons and particulate emissions, energy consumption and space consumption for transport infrastructure construction should be considered into the "environmental" dimension. Costs associated with transport and related to household incomes and locations have to be considered 
Table 1: $\quad$ Set of recommended indicators - source Litman.

\begin{tabular}{|c|c|c|c|}
\hline & $\begin{array}{c}\text { Fundamental } \\
\text { (commonly usage) }\end{array}$ & $\begin{array}{c}\text { Useful } \\
\text { (to use if possible) }\end{array}$ & $\begin{array}{c}\text { Specific } \\
\text { (to use for particular } \\
\text { needs or goals) }\end{array}$ \\
\hline 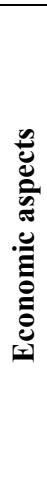 & $\begin{array}{l}\text { - Mobility per capita (pax per km } \\
\text { or trips per day, or per year). } \\
\text { - Modal choice (pax: non- } \\
\text { motorized transportation, car, } \\
\text { public transport; freight: truck, } \\
\text { rail, ship, plane). } \\
\text { - Congestion costs per capita. } \\
\text { - Total transport costs per capita } \\
\text { (vehicle, parking, tolls and } \\
\text { transport services). } \\
\text { - Average travel time and reliability } \\
\text { in commuting. } \\
\text { - Average speed and reliability of } \\
\text { freight transport. }\end{array}$ & $\begin{array}{l}\text { - Relative quality } \\
\text { (availability, speed, } \\
\text { reliability, security and } \\
\text { status) of non-car modes } \\
\text { of transport (walking, } \\
\text { cycling, shared ways, } \\
\text { public transportation) than } \\
\text { using the car. } \\
\text { - Number of public services } \\
\text { accessible by residents } \\
\text { walking a distance of } 10 \\
\text { minutes and job } \\
\text { opportunities walking a } \\
\text { distance of } 30 \text { minutes. }\end{array}$ & $\begin{array}{l}\text { - Percentage of } \\
\text { apartments with } \\
\text { internet access. } \\
\text { - Changes in real estate } \\
\text { value. }\end{array}$ \\
\hline 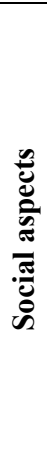 & $\begin{array}{l}\text { - Accidents and road deaths per } \\
\text { capita. } \\
\text { - Quality of transport for } \\
\text { disadvantaged people (disabled, } \\
\text { low income, children, etc.). } \\
\text { - Availability of funds (percentage } \\
\text { of family budgets devoted to } \\
\text { transportation). } \\
\text { - Overall satisfaction rate of the } \\
\text { transport system (derived from } \\
\text { users' surveys). } \\
\text { - Overall plan (consider needs of } \\
\text { disabled people in transport } \\
\text { plans). }\end{array}$ & $\begin{array}{l}\text { - Percentage of residents } \\
\text { that walk or ride bicycles } \\
\text { for health effects ( } 15 \text { 'or } \\
\text { more per day). } \\
\text { - Percentage of children } \\
\text { going to school on foot or } \\
\text { by bike. } \\
\text { - Social Cohesion (quality } \\
\text { of neighbourhood } \\
\text { interactions). } \\
\text { - Level of cultural } \\
\text { resources considered in } \\
\text { transportation plans. }\end{array}$ & $\begin{array}{l}\text { - Low pricing of public } \\
\text { transport. } \\
\text { - Low cost of houses to } \\
\text { rent in accessible } \\
\text { locations. }\end{array}$ \\
\hline 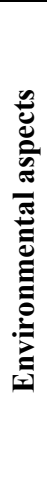 & $\begin{array}{l}\text { - Energy consumption per capita, } \\
\text { disaggregated by mode of } \\
\text { transport. } \\
\text { - Energy consumption per ton / km. } \\
\text { - Pollutant emissions per capita } \\
\text { (various types), broken down by } \\
\text { mode of transport. } \\
\text { - Spaces per capita devoted to } \\
\text { transport infrastructure (roads, } \\
\text { parking lots, etc.). } \\
\text { - Exposure to air pollution and } \\
\text { noise and health damages. } \\
\text { - Impermeable surface protection } \\
\text { and management of rainfall. }\end{array}$ & $\begin{array}{l}\text { - Index of liveability of } \\
\text { communities. } \\
\text { - Emission of water } \\
\text { pollutants. } \\
\text { - Habitat protection. } \\
\text { - Use of renewable fuels. } \\
\text { - Resource efficiency of } \\
\text { transport equipment (use } \\
\text { of renewable materials and } \\
\text { energy efficient lighting). }\end{array}$ & $\begin{array}{l}\text { - Impacts on particular } \\
\text { habitats and } \\
\text { environmental } \\
\text { resources. } \\
\text { - Effects of heat islands. }\end{array}$ \\
\hline
\end{tabular}

into "social" dimension. Behind these indicators that balance performed services and resulting costs, there are some synthetic ones. There are general assumptions of society development: demographic change (population growth, by age groups), economic growth (changes in GDP, income levels), technological 
change (average unit emissions and fuel consumption), changes in sociological (life styles). There are also factors affecting the interface between transport and urban planning: location of activities and population that are indicators of global mobility. Some suggested indicators may be considered essential and they have to be used consistently, while support ones are less used. Other specific indicators are used to consider specific needs or goals. Necessary information to construct indicators is available by sources such as census and surveys on consumers or on transport. Other info is collected during typical urban planning activities. Some indicators overlap: several indicators on displacement ways (quantity and quality of travel choices, modal split, non-motorized transport quality, etc.) and indicators on economic or equitable efficiency. Among the latter a significant impact is attributed to cost-based pricing (i.e. the degree to which prices reflect total costs).

\section{The role of indicators}

The path towards sustainability in the field of urban mobility is long, tortuous and full of unexpected deviations. The plans and strategies required are usually based on an incomplete knowledge of present conditions. Then the resulting predictions are imperfect. So monitoring activity is a necessary complement to urban planning and development. It helps to evaluate, because it assists to be aware of the achievements of previous plans and taken actions. Observation, measurement and evaluation are important steps for the realization of sustainable transport strategies. They are the formulation of priorities, financial analysis, planning and implementation. Urban transport plans become more elaborate and ambitious when they take more account of the links between the transport system and other elements related to quality of life (land use, environmental quality, public health, equality in access to offered options, etc.). Into the future monitoring activities will become more important as urban transport plans will continue to integrate the different dimensions of sustainability. Monitoring efforts should study implemented measures, achieved results and environmental conditions under different perspectives (short, medium and long term), corresponding to time changeable goals/interests, as we can see in table 2 . Communities do not have time and resources to adopt such an ideal approach (often their skills are not expressed at best). Cause-effect dynamic relationships linking goals, targets indicators are rarely clear or defined. So the interpretation of results will be done judiciously and with intuition. For example, it is difficult to understand accurately how an increase in supply of public transport will cause a slight decrease in energy consumption, rather than an improvement of energy efficiency of cars. What is also very difficult to understand is how an increase in the supply of public transport depends on an improved level of service, rather than a decrease in fuel price. So it is important that environmental, economic and social indicators should be developed by defining a consistent observation field both on the explanatory factors of considered activities and on involved decisionmaking powers. This study aims to determine indicators that can be used within a national territory, where institutional instruments are unique and where 
mobility logics have similar characteristics. So it fits in the preparation of urban traffic plans and/or the urban mobility plans. They have the explicit task of coordinating the management and development of all the available modes of transport to get improvements in traffic fluidity, environmental protection, safety, energy consumption and quality of life within the city and the mobility of its hinterland.

Table 2: $\quad$ Three temporal fields of control and monitoring programs.

\begin{tabular}{|c|c|c|c|}
\hline & Long term & Mid-term & Short term \\
\hline ङ్ & $\begin{array}{l}\text { - It defines the framework } \\
\text { of plans, programs and } \\
\text { projects of sustainable } \\
\text { transport. }\end{array}$ & $\begin{array}{l}\text { - It provides information for the } \\
\text { elaboration of plans, programs } \\
\text { and projects of sustainable } \\
\text { transport. }\end{array}$ & $\begin{array}{l}\text { - It provides information } \\
\text { for the elaboration and } \\
\text { evaluation of plans, } \\
\text { programs and projects } \\
\text { of sustainable transport. }\end{array}$ \\
\hline 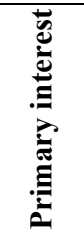 & $\begin{array}{l}\text { - General conditions of } \\
\text { transport and adequate } \\
\text { characteristics of the } \\
\text { collectivity (economy, } \\
\text { environment, land use, } \\
\text { socio-demographic } \\
\text { aspects). }\end{array}$ & $\begin{array}{l}\text { - Status of the transport system } \\
\text { (total investment, results, } \\
\text { performance, impacts). }\end{array}$ & $\begin{array}{l}\text { - Performance measures } \\
\text { (measures put in place, } \\
\text { the results obtained, } \\
\text { efficiency and } \\
\text { performance). }\end{array}$ \\
\hline 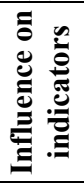 & $\begin{array}{l}\text { - Absent or low - The } \\
\text { actions and indicators } \\
\text { have an indirect link (or } \\
\text { virtually none). }\end{array}$ & $\begin{array}{l}\text { - Medium - measures and } \\
\text { indicators have an indirect } \\
\text { link. }\end{array}$ & $\begin{array}{l}\text { - Medium to high - } \\
\text { actions and indicators } \\
\text { have link more direct as } \\
\text { possible. }\end{array}$ \\
\hline 苞 & $\begin{array}{l}\text { - Emissions of greenhouse } \\
\text { gases per capita. } \\
\text { - Age profile of the } \\
\text { population. } \\
\text { - Trends in air quality. } \\
\text { - Sharing of transport } \\
\text { modes (walking, cycling, } \\
\text { public transport, car). } \\
\text { - Economic impact of road } \\
\text { congestion. }\end{array}$ & $\begin{array}{l}\text { - Number of trips by public } \\
\text { transport system per person. } \\
\text { - Percentage of completion of } \\
\text { the network of cycle paths. } \\
\text { - Percentage of good condition } \\
\text { of main roads. } \\
\text { - Number of accidents involving } \\
\text { pedestrians per annum. } \\
\text { - Level of congestion of main } \\
\text { roads. }\end{array}$ & $\begin{array}{l}\text { - Number in cyclists in } \\
\text { training. } \\
\text { - Punctuality of public } \\
\text { transport service. } \\
\text { - Number in employers } \\
\text { who use home-work } \\
\text { plans of the mobility } \\
\text { manager. }\end{array}$ \\
\hline
\end{tabular}

The development of indicators of sustainable mobility can make a great contribution to enrich these instruments. It also allows you to extend their validity over time. Moreover, the logic of the "tableau de bord" is a very useful tool. It allows to keep always monitored the forecasts and actual results of the elements of the city life (especially those related to urban mobility). It is a part of monitoring of mobility indicators, with reference to the "Conto dei Trasporti". The latter provides a synthesis of the macro-economic costs of public communities, transport field, households and enterprises. It allows to highlight who use money, what he spends and how, at a local level and in every area. Today use of these indicators has to develop and integrate more fully and easily into planning processes, through urban transport plans, urban mobility plans and 
regional transport plans. Proposed economic indicators of sustainable mobility should confirm and complete their information as a tool for decision support.

\section{Conclusions}

Proposed indicators are capable to provide an image of daily mobility and its environmental, economic and social impacts in urban areas. They have to offer an image that expresses the complexity of the mobility, its close ties to the urban and social context, the different involved factors, resulting in multiple points of problem analysis, including human behaviour that is certainly not the lower one. The scholar should try to predict which way the configurations of urban transport will take (with an elevate grade of certainty), what will be their decisive causes and what may be their environmental, social and economic impacts. This task is quite difficult to perform. Under environmental point of view, the balance that city life achieves (between downtown and the suburbs) is linked to different types of mobility and consequent impacts (short-term and local impacts into downtown, long-term and territorial wide-ranging into suburbs). Under social point of view, characterization of residence (on the basis of household incomes) shows very different situations, especially if we consider the residence of the low-income families, often constrained to the suburbs. On the economic front, the limits of the involved actors (the households, the companies, the local communities, the State) result into different feelings of the weight of urban mobility. Proposed indicators cannot be considered separately, because this will take into account only a single facet of the problem. Indicators may have an interest only if they are considered in global terms, by comparing the images obtained by citizens' daily mobility with its three dimensions. Individual mobility is linked to the spatial organization of cities, to its activities and to people residences. It does not allow anticipating trends and easy simple answers. It is useful and prudent to have a tool that can provide multiple perspectives of clarifying information, when different scenarios for the evolution of urban mobility system are tested. So it is important to highlight a combination of measures that allow the progress of a considered dimension, without causing a concomitant degradation of the others. When a global and sustainable planning activity is performed, it is preferable to choose a balanced set of indicators. It should reflect a combination of three dimensional impacts. If a single type of impact is too underlined, decisions will not be optimal. Decision makers should understand perspectives, assumptions and limitations of each indicator. In fact the selection of indicators could bring to the rise of conflicts between the advantages and completeness of the examined ones. A small set of indicators, which uses simple-to-find data, it is more practical to apply. But it may ignore significant impacts and distort the decisions of the planning activities. Instead, a broader set of indicators may have more complete characteristics, but it may have too high collection costs and difficulty to interpretation of data. Currently, standardized set of indicators for planning global and sustainable transport systems do not seem to be available. Each competent Authority or Operator should try to develop their own specific set: it is based on known needs and 
ability in interpretation of each actor. Instead decision makers should use recommended set of indicators of sustainable transport, standards for data collection and good practices of evaluation. So sustainable planning activities would be improved and the comparisons between cities, societies and between different time periods would be possible.

\section{References}

[1] United Nations, General Assembly, Report of the World Commission on Environment and Development "Our common future" (Chairman Gro Harlem Brundtland), 1987

[2] Carta delle città europee per un modello urbano sostenibile, Aalborg, Danimarca, maggio 1994

[3] Levarlet F., Les indicateurs de developpement durable. Méthodes et perspectives, IFEN, Collection Études et Travaux, n² 24, Orléans, 1999

[4] MOST, Moving on sustainable transportation, Transport Canada, 1999

[5] Sustainable Urban Transportation:

[6] Black J.A., Paez A., Suthanaya P.A., Performance Indicators and Some Analytical Approaches, Journal of Urban Planning and Development, December 2002

[7] CST, Sustainable Transportation Performance Indicators, Centre for Sustainable Transportation, 2005

[8] Tira M., Indicatori condivisi per monitorare le politiche per la mobilità sostenibile: il progetto OS.I.MO.S., "La mobilità sostenibile nelle aree urbane", Padova, novembre 2007

[9] Todd Litman, Developing Indicators for comprehensive and sustainable transport planning, Transportation Research Record 2017, TRB, 2007

[10] United Nations, Indicators of Sustainable Development: Guidelines and Methodologies, Third Edition, New York, October 2007

[11] Todd Litman, Sustainable Transportation Indicators. A Recommended Research Program For Developing Sustainable Transportation Indicators and Data, By the Sustainable Transportation Indicators Subcommittee of the Transportation Research Board, November 2008

[12] Kaplan D. and Marzloff B., Pour une mobilité plus libre et plus durable, Limoges, FYP, 2009 